\title{
CORRECTION
}

\section{Correction to: Grassroots urbanism in contemporary São Paulo}

\author{
Daniela Sandler ${ }^{1}$
}

Published online: 8 May 2020

(c) Springer Nature Limited 2020

\section{Correction to: URBAN DESIGN International \\ (2020) 25:77-91 \\ https://doi.org/10.1057/s41289-020-00108-8}

This article was erroneously published in Volume 25, Issue

1 (2020) https://link.springer.com/article/10.1057/s4128

9-020-00108-8

The article will be included in the special issue "Guerrilla Urbanism" once the issue is published.

The original article can be found online at https://doi.org/10.1057/ s41289-020-00108-8.

Daniela Sandler

dsandler@umn.edu

1 School of Architecture, University of Minnesota, 145 Ralph

Rapson Hall, 89 Church ST SE, Minneapolis, MN 55455,

USA 


\section{Abstract}

In the last decade, manifestations of grassroots urbanism have transformed São Paulo into a playfield for creative interventions. Initiatives focus on art, culture, and education; greenery and open spaces; public equipment; water and environmental resources; and gender, race, and class justice. I argue that these initiatives are more than the sum of their parts; they influence social imaginaries, expectations, and urban policies beyond the scope of each case. My research tries to understand crucial differences among initiatives-while some open up spaces for the emancipation of disenfranchised groups, others inadvertently engage in processes of gentrification and exclusion despite claims to representing a diverse public. These differences in goals and outcomes can be understood in terms of the opposition between tactical and insurgent urbanism. As such, the study of these differences is meaningful not only for understanding the case of São Paulo, but also for expanding theoretical debates on grassroots urbanism at a global scale.

Keywords Grassroots urbanism · Insurgent urbanism · Tactical urbanism · Guerilla urbanism · São Paulo · Brazil

\section{Introduction}

Starting around the mid-2000s, manifestations of grassroots urbanism-bottom-up, citizen-led actions to improve common urban spaces—-have transformed São Paulo into a playfield for creative interventions, installations, and events that attempt to humanize the city in a variety of ways (Fig. 1). Initiatives focus on issues such as art, culture, and education; greenery and open spaces; outdoor furniture; water and environmental resources; transportation; and gender, race, and class justice. But not all grassroots urbanism is created equal: some projects have a strong commitment to social and cultural inclusion and political critique, while others are more concerned with aesthetic and material improvements. Some projects actively resist exclusionary processes such as gentrification, police repression, and discrimination, while

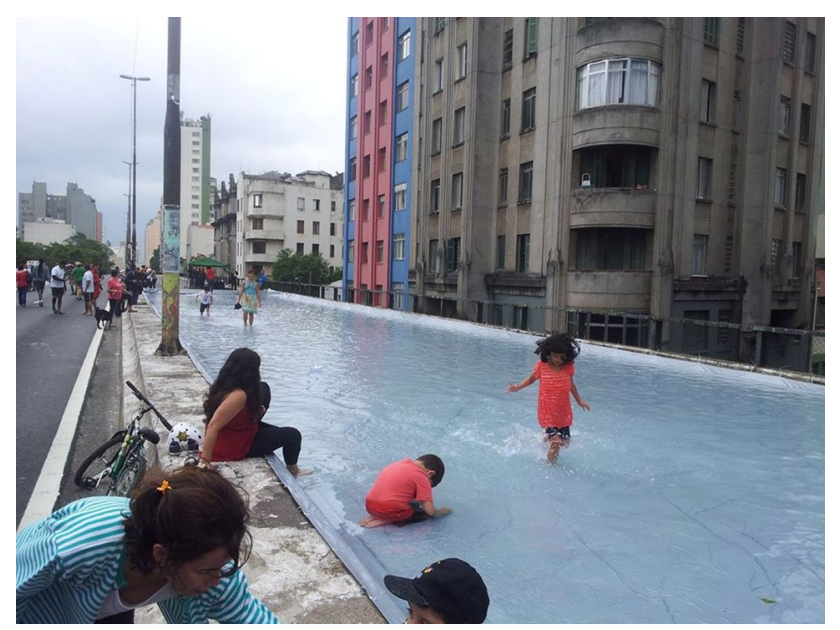

Fig. 1 Temporary swimming pool on top of the Minhocão elevated expressway. The pool was conceived, planned, and built by artist and designer Luana Geiger in March 2014. She used a blue tarp to create a 50-meter-long shallow pool covering up three traffic lanes. The project happened on a Sunday, when the expressway is closed to car traffic. Image credit and copyright: Francine Sakata (2014) others inadvertently collaborate with dynamics of socioeconomic exclusion. These differences, which I will unfold below in connection to São Paulo and also to international theoretical debates on the field, can be understood as differences between tactical and insurgent urbanism, terms I will discuss in more detail later in this article.

In the case of São Paulo, these differences have not been adequately addressed yet by the growing literature on the topic, partly because this literature tends to focus on single case studies or on certain areas of the city (Affonso 2010; Aderaldo 2017; Bortolozzo 2014; Friendly 2017; Maziviero and Almeida 2017; Mesquita 2008, among many others). While such focus affords rich ethnographic depth, it does not allow for wider-ranging conclusions about the role of grassroots urbanism as both a trend and a tool for urban design in a city as complex and unwieldy as São Paulo. What is more, studies tend to privilege central neighborhoods and a few types of grassroots urbanism (design-build public spaces, festivals). These biases, which can be explained by the visibility of a few projects in mainstream and social media, mean that other projects are overlooked, especially when they are located outside of the city's central, wealthier core, and when they do not fit the stereotypes of grassroots urbanism.

These gaps in scholarship cause gaps in our understanding of the potentialities and shortcomings of grassroots urbanism, as evidenced by debates about the topic. Critics of grassroots urbanism in São Paulo commonly condemn it as a bourgeois, hipster phenomenon, guilty of aiding and abetting gentrification, and blind to the city's socio-economic and territorial disparities (Wisnik 2015; Esforçado 2015; L. 2015). ${ }^{1}$ Such criticism ignores the numerous projects in low-income neighborhoods in the periphery of the city,

\footnotetext{
${ }^{1}$ For my statements on public debates on the topic, I rely on a combination of news media, personal interviews, public presentations, and social-media posts on public forums and groups. For socialmedia posts, I use modified initials of individuals to protect their identity. See my discussion of methodology later in the paper for caveats on social-media research.
} 
especially those that do not fit the mold of photogenic selfbuilt outdoor furniture or eye-catching installations and performances. Critics also imply that grassroots urbanism is a zero-sum game, where projects focused on privileged areas of the city threaten to take away attention or resources that could go to the periphery (V. 2015; L. 2015).

Conversely, champions of grassroots urbanism sometimes exaggerate its potential to address urban ills (Mesquita 2008; Bortolozzo 2014; L. Silva 2016; Kwak 2018). While this might be in part due to these authors' desire to boost a movement they believe in, it is also a function of cherrypicking examples that demonstrate the values the authors were interested in a priori. In full disclosure, I admit to sharing these authors' enthusiasm for grassroots urbanism, but I also believe that a stronger case is made by recognizing the limitations of this practice. Not only does this allow for a more realistic picture, but it can also suggest ways to address the pitfalls of grassroots urbanism, and thus make it more effective.

\section{Blind Spots}

Some of the most famous examples of grassroots urbanism in São Paulo illustrate these debates: the design-build transformation of the Potato Square, a project known as The Potato Needs You (2014 to the present), and the Baixo Centro Festival, a music and public art event (organized yearly from 2012 to 2014). These two projects garnered intense attention in social and mainstream media, and were dissected by several scholarly studies in Brazil (L. Silva 2016; Nito and Scifoni 2018; Marino 2018; Silva and Pina 2018; Hori 2018; Mascarenhas 2014; Blümer and Victal 2016; Wassall and Assad 2018; Lima 2017, among many others), also catching the eye of international researchers. In 2016, when I interviewed Lucas Pretti, one of the organizers of the Baixo Centro Festival, he signaled the visibility of the project by mentioning that he had also just been interviewed by a Swedish academic (Pretti 2016).

These two projects are lauded as successful examples of bottom-up initiatives that improved spatial and socio-cultural conditions in challenging areas through creative approaches to funding (crowdsourcing, volunteer work, donations) and collective, multidisciplinary, multimedia design processes. The Potato Needs You transformed an empty concrete plaza into an urban playground for all ages, with permanent and temporary furnishings for lounging, playing, gathering, and performing. The Baixo Centro Festival brought free concerts, visual art installations, and performances to a section of downtown that has suffered with decaying infrastructure, poverty, and congestion for decades. Critics have praised these projects for upgrading public spaces, bringing attention to overlooked or neglected areas, and making cultural activities available for free to a diverse public (Lima 2017;
Wisnik 2016). On the other side of the debate, activists and scholars have chided these projects for privileging a specific segment of the public (white middle-class professionals), for contributing to gentrification and social displacement in their respective locations, and for ignoring severe problems such as homelessness and the systemic socio-economic and urban disparities of São Paulo (Arantes 2016).

While arguments on both sides of the debate have their merits, the debate itself has led to a stalemate, which, I argue, is not productive. First, the impasse tends to throw the baby away with the bathwater: these examples might have shortcomings, but they do offer positive achievements that could inform future projects in revised ways. Second, in these debates, these projects come to stand for all of grassroots urbanism, and the hundreds of other projects that do not fit the mold are ignored not only by scholars and the media, but also by potential supporters or participants.

Take, for example, the Invisible Periphery Association (founded in 2009; Periferia Invisível, n.d.), located in the far east zone of the city, in a vast low-income district lacking resources, infrastructure, and public investment. Operating out of a small, self-built house, the Association organizes public concerts, performances, open-air movie screenings, and debates on urban issues. The Association brings cultural products and experiences to a part of the city that had little access to them, and even when many of those experiences are devoted to leisure and recreation, most of them are at the same time imbued with a critical consciousness of urban conditions and challenges, and a desire to change these conditions.

The association pointedly calls itself "Invisible Periphery." Gustavo Soares, one of the association's members, made a point of reiterating the meaning of the name when I interviewed him: the peripheral zones of the city are overlooked not only by the government but also by the urban elites who, in possession of both economic and political power, influence the allocation of resources and the management of the city as a whole (Soares 2016). In mainstream media, the peripheries are mostly brought up in sensationalist news about shootings, drug gangs, floods, and fires (Comunicação Comunitária 2017; Periferia em Movimento, n.d.). The selective invisibility of the periphery corresponds to a lack of public and private resources, and an excess of race- and class-based police violence (Carril 2006; Estadão 2016; Keinert and Karruz 2002; Baiocchi et al. 2011; Prefeitura de São Paulo 2002). More specifically for grassroots projects, the invisibility means little access to potential sponsors, donors, and publicity.

At the same time, the challenging conditions in the periphery might be one of the factors behind the proliferation of grassroots urbanism in the first place. The dearth of parks, cultural programming, and outdoor furniture has spurred residents to organize themselves in order to fill the gaps. The Invisible Periphery is one example among similar initiatives: 
Cooperifa, a cultural programming cooperative that began as a literary salon; Permaperifa, focused on permaculture; Pretas Peri, a collective devoted to race and gender rights; Periphery in Movement, a journalism collective that counterbalances negative mainstream media coverage of urban issues in the peripheries; São Mateus in Movement, a shared public space devoted to culture and community dialogue; among many others.

The number and variety of such initiatives in the peripheral areas of the city is evidence that grassroots urbanism can succeed in different conditions, adapt to local contexts, and provide tangible benefits to a variety of people. But because these initiatives (like their respective neighborhoods) are outside of the spotlight, they do not partake in the opportunities that come with popular attention: funding, sponsorships, donations, etc. The invisibility also has scholarly consequences: the story is incomplete without accounting for grassroots urbanism initiatives in the periphery. Not only do peripheral initiatives account for about two-thirds of grassroots urbanism projects in the city, as I explain below, but they also offer unique models of organization, participation, and knowledge that could be tapped into for official urban policies.

As a way to provide a fuller, more nuanced account of grassroots urbanism in São Paulo, I deemed it necessary to cover as much of the city as possible, with no prejudice regarding location or project type, so as to overcome not only the biases of existing debates, but also my own expectations of what grassroots urbanism is and where it can be found. For this reason, my research takes a whole-city approach by locating grassroots projects on a digital map, and analyzing geospatial trends and correlations. At the same time, I did not want to lose the nuances that come from focused case studies, so my fieldwork also includes selected examples examined in depth to represent the variety of grassroots urbanism in the city.

This paper is a snapshot of this larger research project, which is still in progress. Here I present preliminary findings of my analysis of grassroots urbanism in the city as a whole, with attention to correlations between types of project and context, and to differences among projects. In order to account for these differences, it is also necessary to refine the terminology associated with grassroots urbanism-adjectives such as tactical, insurgent, everyday, bottom-up, DIY, and guerilla. For this reason, this paper includes a discussion of these terms, meant to clarify their specific meaning in the context of São Paulo, and at the same time to contribute to a broader theoretical understanding of the topic.

\section{Methodology}

This research uses a combination of methods: geospatial analysis; personal interviews with activists, urbanists, and scholars; direct observation; research of traditional news media, social media, and online resources; and bibliographic research of academic publications in urbanism, urban design, architectural history, landscape design, cultural studies, and cultural theory. This project draws from methods and references of urban and architectural history, urban studies, cultural geography, and visual and cultural studies.

Although this project makes extensive use of immersive field research, it is not an ethnography. While I take informants' perspectives into account as sources of information and windows onto cultural imaginaries, my fieldwork also relies on my own thick description and interpretation of spaces. I draw from art and architectural history, in particular from a combination of semiotics, iconography, and socio-cultural history, in order to understand what particular spaces mean, how they mean it, and to what purpose; how they operate at the service of certain agendas, and how they participate in both local processes and citywide dynamics. In addition to my direct observations from site visits, my analysis of space is grounded on the study of spatial representations such as maps, images, videos, census data, historical and contemporary accounts in news sources, and academic publications.

Interviews complement, guide, and inform these spatial analyses. I have carried out twenty-two interviews with grassroots activists, scholars, and urbanists since 2016, mostly in person during annual fieldwork stays in São Paulo, but also remotely via Skype or email. In addition, I glean information on public debates about grassroots urbanism through a combination of traditional news media sources (newspapers, magazines, and online periodicals) and social media and crowd-sourced materials (Facebook posts, blogs, Youtube videos, collective online maps, and other platforms). I recognize the limitations of social-media sources, such as sample bias and the instability of sources-posts can be edited or taken down, links get broken, etc. (Murphy et al. 2014). I do not claim that these social-media sources are representative of broader public perceptions in general; rather, I take them as qualitatively significant voices in multilateral, heterogeneous, and open-ended public debates.

The above methodologies are mostly qualitative and thematic, geared towards a deep understanding of contextual particularities and paradoxes of grassroots urbanism through case studies, valued both as unique phenomena and as representative of more general trends. In order to identify these more general trends, I also resort to a geospatial approach, by locating as many grassroots projects as possible on an ArcGIS map (Fig. 2). The map contains socio-economic and environmental information, such as the Human Development Index per district; the location of environmental resources such as rivers, parks, and open spaces; the distribution of cultural amenities (theaters, museums, cultural centers, libraries), public transportation, and other services; and census data. The layering of this information with the geolocated projects reveals correlations between project 


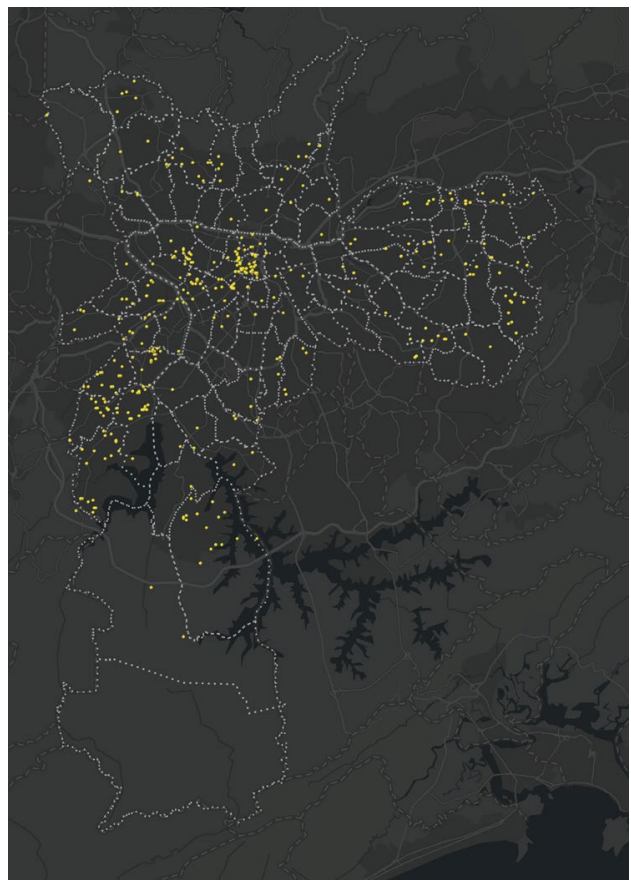

Fig. 2 Grassroots urbanism in the city of São Paulo. Yellow dots represent grassroots projects. Dotted white lines represent the outer limits of the city of São Paulo, and inner-city district boundaries. Map created by Rachel Valenziano and the author on ArcGIS Online/Esri. Copyright: the author

location and type, goals, and makeup. ${ }^{2}$ These correlations not only afford insight into broader trends, but also inform the individual analysis of case studies.

This map is in progress, and has its challenges. The city of São Paulo has about 14.71 million inhabitants (not including the greater metropolitan area), a size which poses difficulties to surveying, data collection, and sample estimation. The size of the city, coupled with the dynamic and often small scale of grassroots urbanism, means that it is hard to estimate the universe of case studies, and therefore to calculate a representative sample. For this reason, the map does not purport to represent the totality of grassroots urbanism in the city. Nonetheless, it allows for provisional or working inferences and hypotheses, especially since a density map of the geolocated grassroots projects (Fig. 3) corresponds to the total population density map of the city, with a concentration of projects in denser areas (this assumes, of course, that we expect to find more projects in areas that are more populous).

I collected information for this map from several sources: public digital maps of activism and cultural projects in the

\footnotetext{
2 The socio-economic and environmental data are not reproduced in the accompanying figures for reasons of legibility. They are present in the digital map as layers that can be turned on and off, and which can feed into statistical analyses.
}

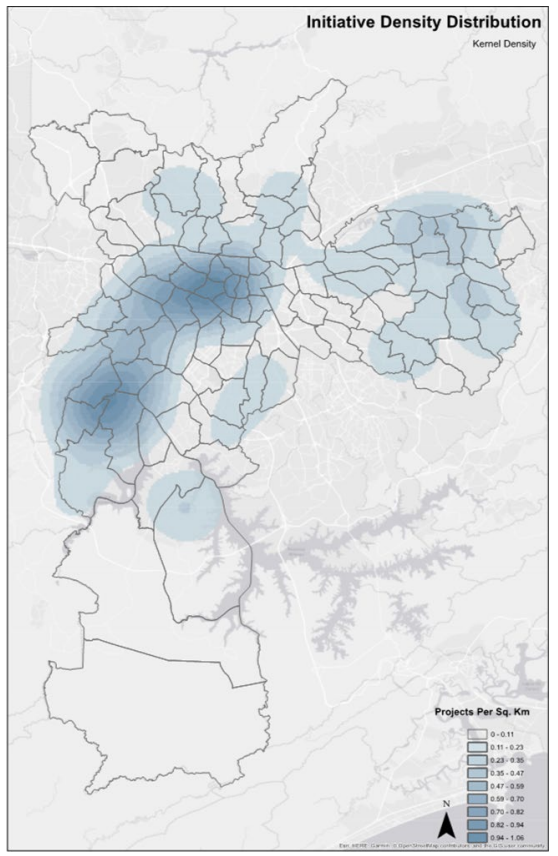

Fig. 3 Density Map of Grassroots Initiatives in São Paulo. Denser areas are in darker blue. Density calculated in ArcGIS based on the number of projects per square meter. Map created by Rachel Valenziano with data from the author. Copyright: the author

city (Secretaria da Cultura da Prefeitura de São Paulo n.d.; Gestão Urbana SP n.d.; Mapa de Afetos n.d.; Mapping the Commons n.d.; among others); qualitative academic studies; snowball sampling through interviews and via links and references posted on websites, blogs, social media, and digital maps; news stories; and direct observation of neighborhoods and sites. There is considerable overlap and redundancy among these sources, allowing me to verify their validity and accuracy, and to gauge the relative popularity or reputation of projects. My digital map of grassroots urbanism in São Paulo currently includes 370 projects, dating from 2004 to the present (this number includes projects that have already ended; given the dynamic nature of grassroots urbanism, this does not detract from the value or achievements of projects).

\section{Design or Culture?}

Unlike the aforementioned criticisms that associate grassroots urbanism with central, wealthier areas, my research suggests that grassroots urbanism in São Paulo is a citywide phenomenon, distributed across the whole city (Fig. 2), in a variety of socio-economic and urban contexts: from dense, commercial areas to middle-class mixed-use neighborhoods to residential, low-income districts. Projects are most conspicuously absent only from residential high-income districts, where the need for self-made urbanism is lower and, in some cases, the use of public spaces is also less intense. 
There are also fewer projects in districts at the extreme southern and northeastern zones, which are much less populated than the rest of the city and, in some cases, present semi-rural or rural conditions. The wide distribution of projects supports my hypothesis that, in São Paulo, grassroots urbanism is an important trend in urban planning and design at least since the mid-2000s.

Projects include a variety of forms and programs: improvised bikepaths, self-built skate parks, flash mobs, open-air cultural events, mobile performance stages, urban agriculture, neighborhood parks, graffiti, food projects, among many others. While these can be found all over the city, there are patterns in their distribution. In order for me to understand these patterns, it was important to distinguish among different kinds of projects, identifying discrete categories to account for their unique characteristics. At first, I developed categories that responded quite specifically to the projects found in my research: art, music, performance, education, sport, design-build, installation, landscape design, public space, youth culture, gender, race, politics, urban agriculture, environment, research, etc. A single project could be identified by more than one of these descriptive categories. While these categories allowed me to do justice to the variety of grassroots urbanism, they were too numerous for a meaningful analysis of recurrent patterns. Therefore, I also created a second classification system based on the main orientation of each project, used in addition to the first classification system (the two systems are complementary in terms of the information and insights they yield).

This second system focuses on the nature of each project. As I collected case studies, visited sites, and did interviews, I began to notice patterns. Projects mostly fell into one of two categories: either they focused on material, spatial, and formal aspects, that is, the physical configuration of urban spaces through outdoor furniture, vegetation, ground coverings, boundaries, and structures; or they attended to the programming of existing spaces, transforming them through temporary uses, events, actions, and the occupation of space through bodies and ephemeral objects. In both cases, projects transformed the city, making it more humane, inhabitable, hospitable, or functional, but they did so through different means. In the first case, the means had to do with what I am calling "design," while in the second case, they had to do with what I am identifying as "culture." I want to reiterate that these terms emerged from fieldwork and case studies, and not from any a priori assumption on my part. In addition, although these terms are used in a binary analysis as I explain below, I understand them as extremes in a spectrum, sometimes overlapping and coexisting, and not as mutually opposite.

The design-focused projects are mostly concerned with form, space, and prescribed functions. They attempt to improve the spaces of the city at all scales, from objects and public furniture to parks and water resources. These initiatives have a concrete, visual, and material focus: pocket parks, design-build projects for public furniture and playground equipment, temporary ludic installations, visually striking interventions, landscaping proposals (Fig. 4). Many of these initiatives are led by architects, designers, artists, or other professionals immersed in the world of visual and creative arts. These initiatives are tangible, and clearly associated with the urban realm through their occupation of visible public spaces. In other words, not much convincing is needed to show that these examples have to do with urbanism and urban design as disciplines and fields of practice that study and reshape cities through material and spatial interventions.

The culture-focused projects, in turn, are mostly concerned with programs and open-ended social uses. At first, they may appear less obviously urbanistic. Their themes, programs, and goals center on art (including not only visual arts but also music, theater, dance, literature, and film), education, and social identities (gender, race, class, and sexuality) (Fig. 5). I base this assertion on the data I have collected in my research in progress; other researchers have also remarked upon this cultural bent of grassroots urbanism in São Paulo (Maziviero and Almeida 2017, p. 13). The cultural projects can also be understood in terms of programming - that is, defining a site's program, which is an essential aspect of architectural and urban design, as integral to place-making as drawing blueprints and building structures.

Finally, other projects - a much smaller number than the previous two-merge both culture and design, as they couple an attention to form and physical interventions with social engagement and cultural programming. This is the case, for instance, with the Microtopia project (Figs. 6, 7, 8), where material transformations such as murals, a blackboard, and a metallic staircase linking public space to an enclosed studio

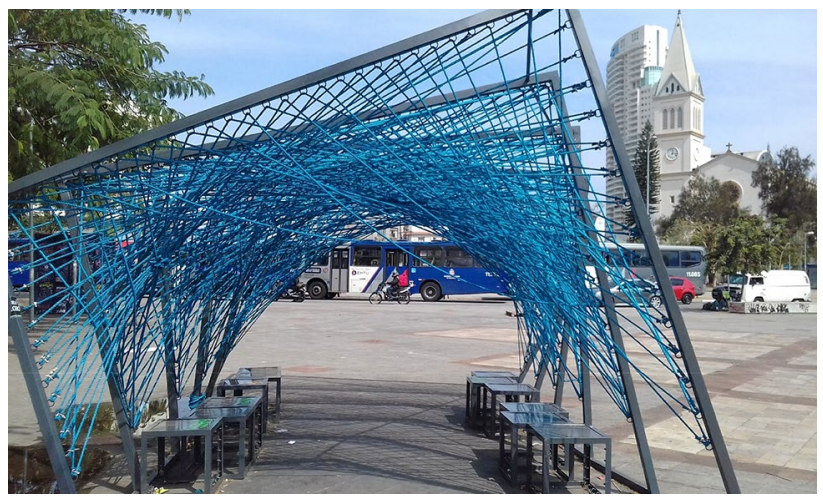

Fig. 4 Quasares Architects, Trançado (Woven) canopy, part of the The Potato Needs You project for the Potato Square, São Paulo. Photo credit and copyright: The Author (2016) 


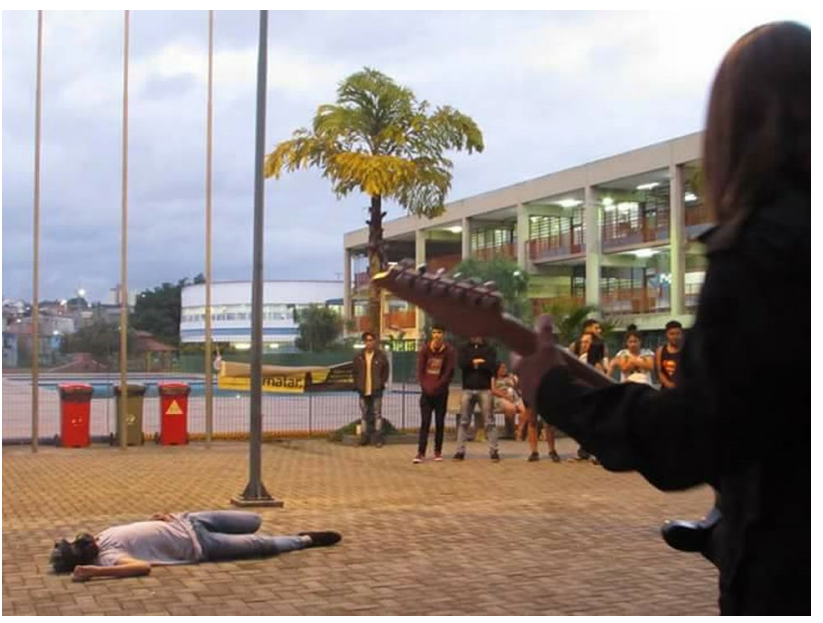

Fig. 5 Bruno Costa (AKA Acadia), Duet for Flesh and Guitar, São Paulo, 2017. Choreography by Bruno Costa. Production, costume, and research by Endersen Carvalho and Bruno Costa. Photo credit: Juan Velásquez (2017). Photo copyright: Bruno Costa

are kept alive by free art and language classes, workshops, and collective art projects.

Distinguishing between culture and design does not mean that these terms are separate, antagonistic, or mutually exclusive; neither does it mean that initiatives only fall into one category without overlap or intersections with the other. I use these two terms as measures of relative emphasis, and not as absolute or essential definitions. In order to account for projects that could be in the middle of the spectrum between design and culture, such as Microtopia, I allowed for a third category: "design/cultural" (hybrid projects where the design and cultural components were even). Once I

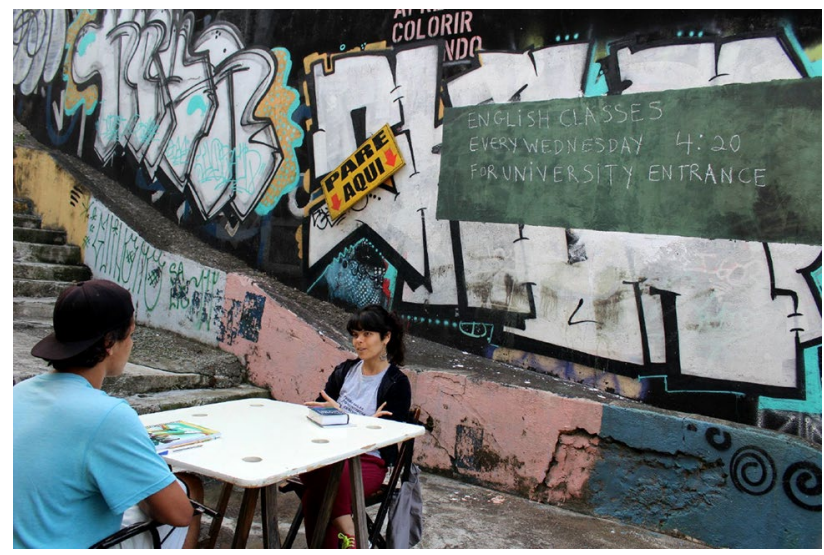

Fig. 6 Microtopia project for the low-income Cambuci neighborhood. The multi-year project has involved improvements to the public stairs seen in this photograph, such as collective cleanups, murals, and graffiti. Here the blackboard announces free, public English-language classes to help prepare for college application exams. Photograph taken by Jeff Anderson, founder and director of Microtopia. Copyright: Microtopia (2018)

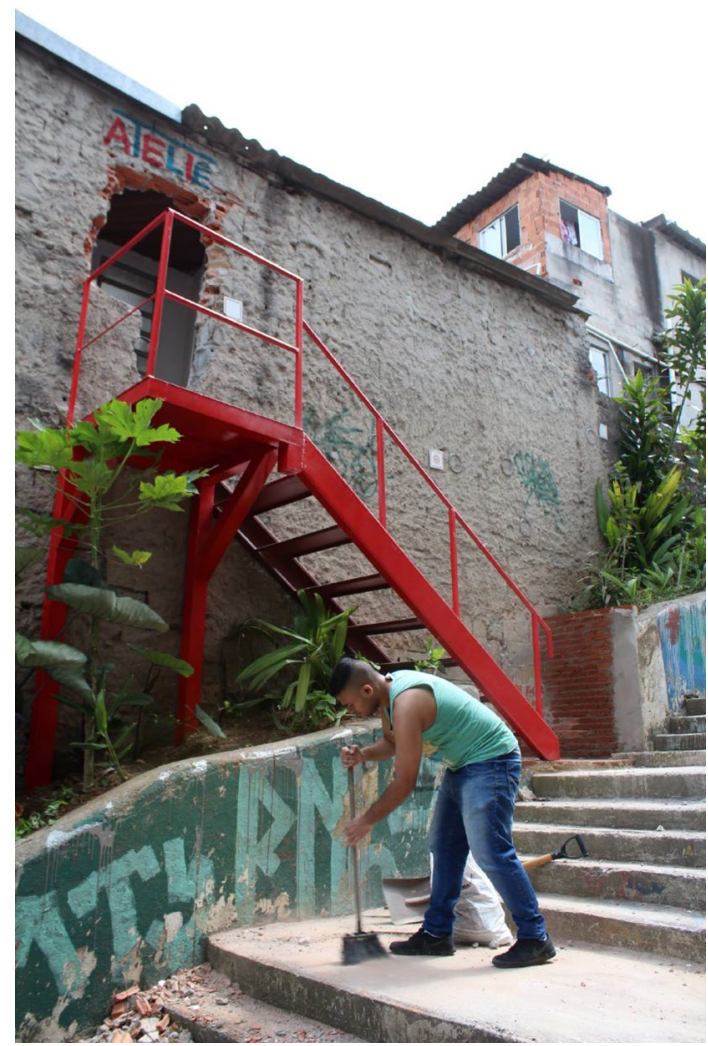

Fig. 7 Microtopia project. The red metallic stairs were installed to connect the public stairs with a studio through an opening punched on the wall. Photograph taken by Jeff Anderson, founder and director of Microtopia. Copyright: Microtopia (2019)

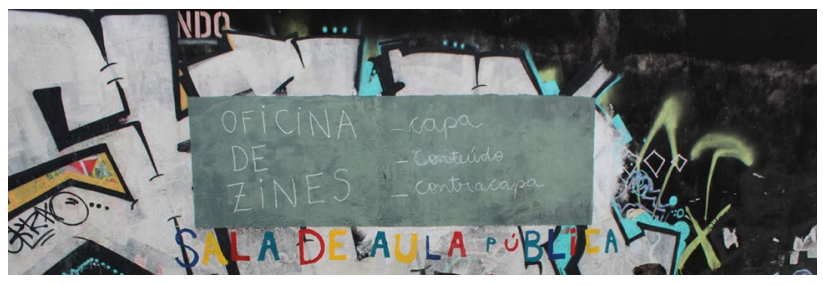

Fig. 8 Microtopia project. Zine creation workshop for children held in the Public Classroom. Photograph taken by Jeff Anderson, founder and director of Microtopia. Copyright: Microtopia (2018)

categorized projects in this way (design, cultural, design/ cultural), a geographic pattern that had already emerged in anecdotal form from my case studies was confirmed quantitatively: for the most part, design projects concentrate in higher-income areas, which in São Paulo correspond to the center and the expanded core of the city; and cultural projects are more prevalent in lower-income areas, mostly in the peripheral zones of the city (Fig. 9).

As mentioned earlier, the sample includes 370 projects. There are 114 projects in the center and 256 in the periphery. Based on the distinction between culture and design 


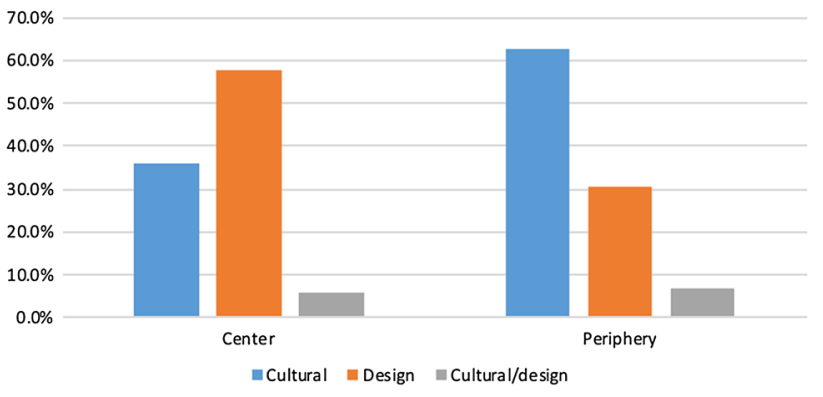

Fig. 9 Distribution of grassroots urbanism projects in São Paulo according to type (cultural or design) and location (center or periphery), based on geospatial data from the map in Fig. 2. Image credit and copyright: the author

explained above, I categorized 201 projects as culture, 144 as design, and 25 as hybrids of culture and design. As shown in Fig. 9, the hybrid category appears in almost equal proportion (between 6 and 7\%) in the center and in the periphery of the city. Removing this hybrid category from the analysis, due to the similar proportion and relatively small share, and focusing on the two main categories, a differenceof-proportions test shows that projects in the periphery are significantly more likely than projects in the center to be culture-oriented (67\% vs. 38\%). This 29 percentage-point difference is statistically significant $(p<0.001$, which means that there is less than a one-in-a-thousand probability that we would observe such a large gap simply due to chance). To put it another way, as the chart shows: in the center, about $60 \%$ of the projects focus on design, and in the periphery, about $67 \%$ focus on culture. The percentages are essentially flipped.

Although it is difficult to estimate the total size of the universe of grassroots urbanism in the city, the density map of grassroots projects corresponds to the demographic density distribution in the city. And we can also understand this correspondence in numbers. Depending on how one counts it, anywhere between 6 and 9.5 million people live in the peripheries (this depends on varying criteria for district and region borders; see Prefeitura de São Paulo n.d.). The whole city has 12-14 million people. This means that anywhere from half to two-thirds of the city's population live in peripheral zones. In my map, about one-third of the projects are in the center and two-thirds in the peripheries, roughly corresponding to the population distribution. If we assume that projects happen where people live, we would expect a breakdown similar to the one I found in my sample, suggesting that my map is a reasonable approximation of all projects. This finding also indicates that grassroots urbanism is a citywide phenomenon that crosses geographical and socio-economic borders in a very unequal city, while at the same time retaining important differences that correlate with socio-economic contexts.
My research demonstrates that grassroots urbanism is not restricted to hipster circles or the white middle-class, calling into question the aforementioned criticism that grassroots urbanism is elitist. Rather, as an approach, it responds and adapts to context. One needs to specify the kind, goals, modes of operation, and outcomes of grassroots urbanism projects before deeming them elitist or inclusive, complicit or contestatory. This conclusion might sound obvious, but in the oft-Manichean debates in São Paulo, restating it helps to temper down both apologists and skeptics.

Perhaps most importantly, the pervasiveness and flexibility of grassroots urbanism, and its intrinsic connection to local communities and participatory, bottom-up processes, suggests that there is a political dimension to the practice. In other words, in São Paulo, a considerable part of the population is already primed for a culture of urban participation and proactive urban management and transformation, mostly at the local level but also often with an awareness of systemic and citywide dynamics and forces. Pessimistically, or cynically, one could interpret this urban-political culture of participation as a reaction to insufficient and retrenching public policies and investments. Optimistically, one can view it as a sign of political autonomy, whereby citizens do not wait for official decrees or handouts, but interact with the government and planning structures in proactive ways.

Some of the interviews I conducted confirm this optimistic interpretation (without excluding the pessimistic oneprojects that start out as reactions to a pressing need can morph into a proactive position of self-determined agency). Agents of grassroots urbanism do not see themselves as separate from public policies, or as filling in for them. Rather, they engage in dialogues and even cooperation with official planning venues in a variety of ways. For example, the Invisible Periphery Association relies on several forms of public funding, such as competitive grants and subsidies (these subsidies, such as the Program for the Valorization of Cultural Initiatives and the Law in Support of the Periphery, were created in the last two decades in order to redistribute resources and address the historic lack of public and private investment in the periphery; see Bonduki 2019; Câmara Municipal de São Paulo 2016; Lemos 2010). This is the case with many other projects in low-income areas where crowdfunding and private sponsorships are not an option due to the economic makeup of their communities. These projects exemplify the intertwining of grassroots and official urbanism at the level of economic and material resources.

Dialogues also happen at the level of policy-making and urban governance. The Potato Needs You group, which fills most of its financial needs through crowdfunding and donations (of materials, labor, or money), has worked to have a voice in official government discussions and to comply with urban legislation. The group's members participate in decision-making meetings and assemblies organized by the local 
district administration-in São Paulo, the city government is organized both trough the central mayor's office as well as a distributed network of district-based offices or "subprefectures," a structure meant to decentralize and democratize policy decisions and city-management. This ongoing participation in official instances is central to the mission and principles of the Potato Needs You group, which at the same time insists on maintaining its independence from political parties or government positions.

These two examples show that grassroots urbanism in São Paulo is not a parallel stream to official urbanism, nor is it a Bandaid to failing policies. Rather, grassroots urbanism is an already established channel for interacting with public structures and resources, allowing for a permeation between the formal and the informal, the bottom-up, and the top-down. This has implications for public policy. Governments and planners interested in participatory, inclusive urban planning might consider involving local populations more intentionally and systematically, tapping into a social force that already exists. Local populations should be valued as sources of knowledge - a knowledge that complements the disciplinary skills and approaches of professionally trained planners.

Involving local communities might also result in greater success for projects, not only because local populations might be more likely to use and care for projects in which they invested their efforts and ideas, but also because such projects are based on their self-defined needs and goals (as opposed to assumptions made by outside experts). I do not mean to suggest that the government should exploit the free labor of grassroots urbanists, or to give up its own role, but rather that the government could find more ways to support grassroots agents and include them in decision-making and civic debates.

If the conclusions above apply to grassroots urbanism in the whole city, they do not explain the difference between grassroots urbanism at the center and in the periphery, or between design and culture. In wealthier areas at the center, as mentioned above, initiatives focus on design. My interpretive analysis of case studies suggests that these projects tend for the most part to assume the status quo of the city as a given-a status quo that equals extreme socio-economic disparities, pervasive poverty around pockets of wealth, crime, police violence, gender and race discrimination, inadequate infrastructure, poor environmental conditions, etc. Designfocused initiatives in wealthy central areas leave the status quo untouched, either assuming it as a precondition of the urban, or treating it an externality beyond the transformative power of design.

Some of these initiatives upgrade or beautify urban spaces, such as pocket parks in upper-middle-class neighborhoods such as Jardins and Moema. Because these neighborhoods are already privileged, these interventions have a mostly "net-zero" effect in terms of social inequality. Other initiatives end up participating in processes of gentrification and social displacement, especially in areas undergoing transition. This is the case with the Baixo Centro Festival, which took place in a central area that had been predominantly lowincome for decades (Lima 2017). When the festival began in 2012, the area was starting to change with an influx of young middle-class professionals, creative businesses, and hip bars and restaurants. The gentrification of the area predated the festival - the festival was in a way a sign of this gentrification. But the festival helped catalyze the process by projecting a positive image of an area previously riddled by negative associations, and by attracting new publics who might have otherwise not ventured there.

The Potato Needs You project was similarly entwined with larger processes of social displacement, even if inadvertently. It began when middle-class residents of the neighborhood of Pinheiros, many of them young and working in creative fields, joined forces as a reaction to a redesigned public space called Potato Square (A Batata Precisa de Você 2015). The Potato Square used to be a busy bus terminal and connection center, and a bustling center of popular commerce, from low-cost independent shops to street vendors. The city transformed the area into a tidy transit terminal, adding a new subway station and reorganizing not only the bus stops but also the tangled sidewalks around them. The new space, unveiled in late 2013, was a vast empty concrete plaza. A group of local residents that called themselves The Potato Needs You began occupying the plaza with meetings and gatherings, and transforming it with self-built equipment and greenery. The Potato Needs You humanized the space, counteracting the sanitized urbanism of the government. But at the same time, by making the space more hospitable and appealing, it ended up contributing to the overall beautification and upgrading of the area. Such upgrading was one of the goals of the revamping of the Potato Square with the new subway station; in addition, the government used eminent domain to consolidate and sell land parcels to private developers in the blocks adjacent to the new square. In other words, the official urban redesign of the area had always aimed at private redevelopment and increased real estate values; by making the Potato Square more attractive, the Potato Needs You ended up collaborating with these goals even if it did not mean to do so.

In contrast, projects in low-income areas take socio-economic conditions and processes as their starting point, main focus, and goal. They might not necessarily depart from the urban as a physical or designed space, instead turning their attention to the social relationships that happen in the urban realm and the political and economic conditions that form this realm. As a result, their primary focus is not necessarily on material or aesthetic improvements, which is not to say that these are absent from their actions. Their consideration 
of formal and material aspects, however, does not always fit the standards or expectations set by official planning institutions and professional training. As Paulo Silva notes, grassroots visions of beauty are diverse and rooted in the local (P. Silva 2016, p. 1047). At the same time, they do not ignore the urban, nor do they treat it as mere background setting for other activities. Rather, these groups understand these activities, and the socio-economic conditions behind them, as always already bound up with the urban in a variety of ways.

For example, the Invisible Periphery Association revolves around the periphery as both a site and an urban concept. The association engages its immediate neighborhood, which sorely needs spaces for the production and enjoyment of art, culture, and music; at the same time, the association conceives itself in solidarity with all peripheral areas in the city (far flung on the southern, eastern, western, and northern edges of the city), which are distant from each other geographically, but close in terms of socio-economic and spatial makeup. The Association addresses the "peripheral condition" in its activities, such as thematic debates, assemblies, and movie screenings, including not only titles about the city's peripheries, but also foreign ones, such as the French movie La Haine (a 1995 production about the Parisian banlieue) (Soares 2016), understanding itself not merely as a product of specific local circumstances, but also as an outcome of broader processes of exclusion and inequality in São Paulo, Brazil, and the world. In addition, the Association goes beyond such conceptual insights, striving for actual collaboration and connections among similar projects located in other peripheral areas in São Paulo. The programs offered by the association thus reveal a deep consciousness of urban conditions and processes, and a desire to counteract these processes by offering opportunities for social inclusion, reflection, and engagement.

With such deep differences in terms of goals, modes of operation, ideological and political commitments, and even understandings of the "urban," can all of these examples be grouped under the same umbrella? They all, I argue, fall within the very broad characterization of "grassroots urbanism," but at the same time they represent different types of grassroots approaches. They can be understood not only according to the design/culture spectrum specific to São Paulo, but also to corresponding terms found in international literature on the field: design-focused projects at the center tend to fall for the most part within the category of tactical urbanism, while culture-focused projects in the periphery tend to align with insurgent urbanism. These categories of course are not static, and not every project falls neatly within them; there are insurgent design projects and tactical ones focused on culture. But these are outliers, and on the whole the distinction between tactical and insurgent is helpful to connect the specific context of São Paulo to broader theoretical debates. For this, a discussion of terminology is necessary.

\section{Grassroots Urbanism}

I have been using the term "grassroots urbanism" in this paper to cast as wide a net as possible over instances of citizen-led urbanism in São Paulo. The expression is intentionally broad, so as to include the variety of positions and approaches represented by more specific terms such as tactical, DIY, everyday, informal, insurgent, and guerilla. I use the term "grassroots" to connote the bottom-up, noninstitutional, non-governmental character of projects, without judgment as to their agendas, locations, and modes of operation. This follows the broad usage of the term by other scholars who apply it to a range of practices that go beyond and even predate tactical urbanism, such as self-built architecture, neighborhood associations, and participatory urban planning (Jiménez et al. n.d.; Diaz and Torres 2012; Siwi 2018). As Paulo Silva notes, not only does informal urbanism have a long history, but even what we understand as "tactical urbanism" is much older than the current scholarly attention to the term suggests (P. Silva 2016, p. 1044).

Using the word "grassroots" does not mean I ignore more sharply defined terms. They figure in my work as a way to understand differences among grassroots projects. But the proliferation of terms, corresponding to a publication boom and rising public interest in the topic, can sometimes be confusing; many terms overlap or mean the same thing, while others harbor important differences in theory and practice. I will briefly address the wide range of terms associated with the field, grouping them into fewer categories as a way to identify key approaches in grassroots urbanism.

The first category includes terms such as bottom-up (Arefi and Kickert 2019), handmade (Rosa and Weiland 2013), doit-yourself (Douglas 2018; Kinder 2016; LaFrombois 2018; Walljasper 2007), and tactical (Lydon et al. 2015). These terms are usually applied to small-scale projects whose delimited scope makes it possible for them to be "handmade." The projects tend to focus on open spaces such as plazas, parks, sidewalks, outdoor furniture, and empty lots. From parklets to yarn-bombing, these projects are concerned with material interventions that reshape the physical and visual configuration of urban spaces; in other words, they have a strong "design-build" character and focus on form, materials, function, and program. Projects in this category are sometimes ephemeral, identified as temporary urbanism (Bishop and Williams 2012). Many are conceived in an intentional and even contrived manner, often with the participation of design professionals, in what scholars have called the co-created or collaborative city (Ermacora and Bullivant 2016; De Lange and de Waal 2019), while other projects are spontaneous and arise out of quotidian practices 
and needs, grouped under monikers such as everyday (Chase et al. 2008) and practical urbanism (Shepard 2017). More recently, scholars and non-academic critics have also associated these projects with contemporary trends such as crowdsourcing and the sharing economy, using terms such as user-generated (Kushins 2013), sharing (Shareable 2018), open-source (Jiménez 2014), and even enterprising (Knudsen et al. 2014).

Although this first category captures the proactive and results-oriented drive of grassroots urbanism, it does not necessarily entail political or critical components. Just like the design-focused projects in São Paulo, projects in this first category assume the status quo of cities as a precondition that they usually do not touch upon or contest in substantive ways. Regardless of whether the people behind these projects agree with the status quo, their initiatives work within the existing city, sometimes inadvertently reinforcing exclusionary dynamics such as gentrification and segregation. In fact, by improving the existing city (with labor and resources usually donated by activists themselves as opposed to being financed by taxes or other forms of public investment), they sometimes end up making it easier for the government to downsize public services (Kinder 2016).

A second bucket of terms attempts to theorize more engaged approaches, which privilege social involvement, participation, and debate. The process of coming together and generating projects and ideas collectively is as important, or sometimes even more prominent, than the product (P. Silva 2016, p. 1045), through concepts such as commoning (Dockx and Gielen 2018; Borch and Kornberger 2015; Dellenbaugh et al. 2015) and community practice (Miazzo 2014). These projects are often born out of pressing necessity, as in what Heben calls "tent-city urbanism" (2014), overlapping with older terms such as self-built architecture but taking on a larger dimension at the urban scale and as a planning approach (Caputo et al. 2019). The improvised, piecemeal, and haphazard quality of some of these make them appear "messy" (Chalana and Hou 2016), while still maintaining a potency and intentionality that distinguishes them from random phenomena.

Other projects take a more intentional critical position, identifying urban problems-spatial, cultural, social, economic, political-and addressing them explicitly. They attempt to claim or reclaim urban spaces or urban rightssuch as the right to housing, greenery, education, diversity, and transportation (LaFrombois 2018; Hellman et al. 2018). Some of these are grounded in the digital hacking culture, with the idea of using existing structures and spaces and tweaking or twisting them to different uses-scholars have called this approach hacking and recoding the city (Ermacora and Bullivant 2016; De Lange and de Waal 2019), and in some cases the projects actually make use of digital technologies and platforms to further their goals.
And finally, some projects in this engaged category push their criticism to subversive, disruptive, and even aggressive lengths. They do not necessarily attempt to remedy an urban injustice or fix a problem, but try to interrupt the "business as usual" of contemporary capitalist cities in order to draw attention to particular issues, from water scarcity to consumerism, from gender violence to racism. These have been called insurgent (Hou 2010; Holston 2008) and guerilla (Hou 2010) urbanism.

This discussion of terminology is meant not only to clarify my use of the term "grassroots," but also my interest in teasing out the different varieties of grassroots in São Paulo as they fall within (or outside) of these various terms and categories. I do not take this terminology as a fixed lexicon, as our field of study is still configuring itself and not all of these terms have equal currency; moreover, some of them overlap, and future theoretical debates might wish to engage and refine our conceptual arsenal. Here, I am more interested in using these terms to understand the case of São Paulo-and also to use São Paulo as a way to expand the definitions and implications of these terms.

As mentioned earlier, most of the design-focused projects at the center of São Paulo correspond to tactical urbanism, and most of the culture-oriented projects in the peripheries to insurgent urbanism. In this way, the theoretical distinctions of international debates on the topic help draw lines in the case of São Paulo, and to highlight the political implications of different kinds of projects. Is it enough to be tactical in a city as divided and unequal as São Paulo? Is insurgency always effective or progressive? Are projects always already compromised by a focus on design, form, and aesthetics, or can these also be put to critical and subversive uses? Can insurgent and tactical urbanisms somehow come together and join forces, becoming more than the sum of their parts, or is grassroots urbanism intrinsically fragmented and scattered, incapable of "scaling up" beyond the ultra-local?

Here is where the design-culture opposition, which started as a specific analytical response to São Paulo, can come to bear. Part of my argument is not simply that the culture-focused urbanism of the peripheries tends to be more emancipatory from a socio-economic and political standpoint; it is also that in order to understand the power of this urbanism, we need to expand our notion of urbanism in the first place. The focus on "culture" does not consign these projects to the realm of artistic expression, folklore, or event programming. Rather, I posit that they are and should be understood as urbanism; they are indissociable from their specific urban contexts, and from the city in general. Their goals and effects unfold onto these urban contexts in ways that are spatial, architectural, visual, and programmatic. They point to the role of 
culture in urbanism, and to the social production of space (Lefebvre 1991).

\section{Culture as Urbanism}

The connection between culture and urbanism is not new. Several theorists and policy-makers have studied the role of culture as a means to upgrading urban spaces, boosting local economies, and drawing further investment and development. Some theorists are critical of this instrumentalization of culture (Paddison and Miles 2007; Kara José 2009; Zukin 1987; Florida 2017; Kaltmeier 2011, etc.), while others have advanced the idea as a panacea to post-industrial urban ills (Florida 2002, 2005; Borja and Castells 1997; KEA European Affairs 2006). The instrumentalization of culture - whether promoted or criticized - is anathema to the bottom-up, democratizing potential of grassroots urbanism.

Another strand that links culture and the urban can be seen in the UNESCO-enshrined parlance on intangible heritage, where culture is treated as a positive asset that can empower communities, including minorities and disenfranchised groups, helping them assert their identity, and providing means of subsistence and paths to historical preservation (UNESCO 2013, 2016; Duxbury et al. 2016). In these cases, culture is understood as connected to the social practices of groups struggling to assert their rights, which would come closer to the emancipatory potential I see in the peripheral urban activism of São Paulo. But unlike the São Paulo case, the heritage view of culture is mostly a non-territorial phenomenon that attaches to the urban as a bonus. Although its site-specificity is recognized as important, the emphasis is on an anthropological perspective that pushes space to the background as a stage-set for the "main show" of culture. This, again, is different from the culture-focused projects of São Paulo, where the urban is a precondition for action, the means through which action happens, and the object of transformative action.

A third approach is offered by literary and cultural studies, in the consideration of urban culture as aesthetic manifestations-literature, music, fashion, visual and performing arts, slang (Jenks 2004; Williams 1975, 1983; among many others). Here urban culture can be understood both as a representation and a product of city life, in a mutually constitutive relationship. Although this connotation might seem more far removed from the realm of urbanism and more aligned with the arts, it offers productive intersections for reflecting about the São Paulo case, where culturally oriented grassroots urbanism came out of a vibrant art and music scene in the periphery.

Finally, there is an approach that is closest to the intertwining of culture and space as mutually productive and transformative, treating cultural manifestations as intrinsically connected to specific places. This approach is present in urban anthropology, landscape and urban studies, and geography, and it is the most aligned with what I propose here in that it sees culture as irrevocably bound up with space, capable not only of expressing spatial relationships but also of changing them (Low 2000, 2017; Holston 2008; McDonogh and Wong 2005). In other words, culture is already seen as sited and site-specific, and spatial aspects are inseparable from social or cultural ones. Space is not a stage-set, but rather produces culture and is in turn produced and transformed by it. I emphasize the ideas of production and transformation because they speak to one of the tenets of urbanism, which is to intervene in some way-to respond, transform, direct, support, create, plan, or reform urban environments.

This proactive inclination also approximates culture to design, when design is understood in its etymology not only as "to draw" but also "to designate," in the sense of specifying, assigning, determining, and directing. In a way, the insurgent urbanism of the São Paulo periphery can be understood as design insofar as groups attempt to determine new conditions for their environment, to direct their environment towards a particular path. By contrast, the handmade urbanism of the center of São Paulo can be understood as "design" in the other sense, that is, "drawing"-drawing, creating, and building objects and visuals that might improve city spaces without necessarily transforming social relations. In this "drawing" meaning of design, the socio-economic conditions of the city are predetermined and taken as a given, that is, they are designated by someone or something else (history, the elites, the government, the forces of the market).

\section{Conclusion}

One of the most significant ways in which grassroots urbanism of any kind can make a difference is in changing citizens' expectations about their environment, and showing what a city could be, or should be. Grassroots urbanismwhether a design-build playground or a movie screening on the street-is by definition small in scale, improvised, adaptive, and dynamic. Its power is to plant ideas in people's minds, to nudge or jolt them towards a different kind of urban life, whether through measured criticism or angry revolt. The lesson from the periphery is not just one of particular examples of resilience and creativity. It is also a lesson about shifting disciplinary thinking. If the social, cultural, and artistic initiatives in the periphery can transform spaces and ways of using and perceiving the city, they might prompt us to expand our notion of insurgent urbanism in particular, and urbanism in general.

This is significant because in São Paulo, informal urbanism initiatives are not completely separate from the formal and institutional spheres of the government. As mentioned 
above, associations and collectives rely on public support in a variety of ways: competitive grants (Prefeitura de São Paulo 2014, 2016), public cultural facilities and services, and educational programs. Recognizing the value of alternative practices outside of the usual arsenal of urbanism might help broaden the reach of these programs, and spur the creation of new programs and ways of supporting initiatives. This goes along with other scholars' suggestions for incorporating tactical urbanism lessons into official planning (P. Silva 2016, p. 1049).

This fluidity between the formal and the informal also undoes a common assumption about grassroots urbanism: that it is completely independent and non-governmental. In the case of São Paulo, in part because of the socio-economic inequalities mentioned above, such separation is not realistic. The fluidity between formal and informal is also, on another level, concerning. To what extent can these initiatives survive without public support? Currently in Brazil, there is a turn to conservatism at every level. Since 2016, conservative politicians have been elected to federal, state, and city governments-including the city of São Paulo. They have campaigned on promises of fiscal austerity, and have begun to implement budget cuts in arts, culture, education, public health, and social services (Sampaio 2019; Saldaña 2019; R. 2019; Estadão Conteúdo 2019; Alessi 2019; Torres Freire 2019; Darlington and Casado 2019), while also attempting to privatize public spaces such as parks, river shores, and the underside of bridges and viaducts (Agência Estado 2019; Stochero 2019; Seto 2019; Redação 2019).

Will this mean a difficult time for grassroots initiatives? Will they be fewer, less active? I want to believe, of course, that this will be the time for grassroots activism to show its full power-to show it can survive, and thrive, even under hostile conditions; to show that there is hope, in São Paulo and beyond.

\section{References}

A Batata Precisa de Você. 2015. Ocupe Largo da Batata: Como Fazer Ocupações Regulares no Espaço Público, pamphlet. São Paulo: A Batata Precisa de Você, Prefeitura de São Paulo.

Aderaldo, G. 2017. Territórios, Mobilidades e Estéticas Insurgentes. Refletindo sobre Práticas e Representações Coletivas de Realizadores Visuais nas Metrópoles Contemporâneas. Cadernos de Arte e Antropologia 6 (2): 31-48.

Affonso, E. 2010. Teia de Relações da Ocupação do Edifício Prestes Maia. Master's thesis, University of São Paulo, São Paulo.

Agência Estado. 2019. Prefeitura de SP Repassa Áreas de Baixo de 3 Viadutos à Gestão Privada, R7, June 8, https://noticias.r7.com/ sao-paulo/prefeitura-de-sp-repassa-areas-de-baixo-de-3-viadu tos-a-gestao-privada-08062019. Accessed January 29, 2020.

Alessi, G. 2019. A Cultura na Corda-Bamba dos Cortes de Gastos no Estado de São Paulo. El País Brasil, April 9, https://brasil.elpai s.com/brasil/2019/04/08/politica/1554741080_908161.html. Accessed January 29, 2020.
Arantes, P. 2016. In-Person Interview. São Paulo: Universidade de São Paulo.

Arefi, M., and C. Kickert (eds.). 2019. The Palgrave Handbook of Bottom-up Urbanism. Cham, Switzerland: Palgrave Macmillan.

Baiocchi, G., et al. 2011. Bootstrapping Democracy: Transforming Local Governance and Civil Society in Brazil. Palo Alto, CA: Stanford University Press.

Bishop, P., and L. Williams. 2012. The Temporary City. London: Routledge.

Blümer, M.P., and J. Victal. 2016. A Porosidade no Largo da Batata, em São Paulo [SP]: Cultura como Patrimônio Imaterial na Cidade Contemporânea. Labor e Engenho 10 (3): 313-325. https://doi. org/10.20396/lobore.v10i3.8646113. Accessed January 29, 2020.

Bonduki, N. 2019. In-person Interview. São Paulo.

Borch, C., and M. Kornberger. 2015. Urban Commons: Rethinking the City. London: Routledge.

Borja, J., and M. Castells. 1997. Local and Global: The Management of Cities in the Information Age. New York: Routledge.

Bortolozzo, G. 2014. Espacialidade e Ativismo Social na Zona Leste de São Paulo: O Caso do Coletivo Dolores Boca Aberta Mecatrônica de Artes. Master's thesis, State University of São Paulo, Rio Claro.

Câmara Municipal de São Paulo. 2016. Lei n ${ }^{\circ}$ 16.496, de 20 de Julho de 2016, http://documentacao.camara.sp.gov.br/iah/fulltext/leis/ L16496.pdf. Accessed January 29, 2020.

Caputo, S., et al. 2019. Values for Self-build Urbanism. European Planning Studies 27 (6): 1200-1216.

Carril, L. 2006. Quilombo, favela e periferia: A longa busca da cidadania. São Paulo: Annablume, Fapesp.

Chalana, M., and J. Hou. 2016. Messy Urbanism: Understanding the 'Other' Cities of Asia. Hong Kong: Hong Kong University Press.

Chase, J., et al. 2008. Everyday Urbanism. New York: Monacelli Press.

Comunicação Comunitária. 2017. Virada Comunicação Discute Representação das Periferias pela Mídia. Fundação Tide Setúbal, News, September 28, https://fundacaotidesetubal.org.br/notic ias/3800/virada-comunicacao-discute-representacao-das-perif erias-pela-midia. Accessed January 29, 2020.

Darlington, S. and L. Casado. 2019. Brazil Fails to Replace Cuban Doctors, Hurting Health Care of 28 Million. New York Times, June 11, https://www.nytimes.com/2019/06/11/world/americas/ brazil-cuba-doctors-jair-bolsonaro.html. Accessed January 29, 2020.

De Lange, M., and M. de Waal (eds.). 2019. The Hackable City: Digital Media and Collaborative City-Making in the Network Society. Singapore: Springer.

Dellenbaugh, M., et al. 2015. Urban Commons: Moving Beyond State and Market. Basel: Birkhäuser.

Diaz, D.R., and R.D. Torres. 2012. Latino Urbanism: The Politics of Planning, Policy and Redevelopment. New York: New York University Press.

Dockx, N., and P. Gielen. 2018. Exploring Commonism: A New Aesthetics of the Real. Amsterdam: Valiz.

Douglas, Gordon C.C. 2018. The Help-Yourself City: Legitimacy and Inequality in DIY Urbanism. Oxford: Oxford University Press.

Duxbury, N., et al. 2016. Why Must Culture be at the Heart of Sustainable Urban Development? UCLG - United Cities and Local Governments, http://www.agenda21culture.net/sites/default/files /files/documents/en/culture_sd_cities_web.pdf. Accessed January $29,2020$.

Ermacora, T., and L. Bullivant. 2016. Recoded City: Co-Creating Urban Futures. London: Routledge.

Esforçado. 2015. Facebook post, March 7, https://www.facebook. com/Esforcado/photos/a.496214830460327/826583407423466 /?type =3\&theater. Accessed January 29, 2020.

Estadão. 2016. IDH: Os 20 melhores e os 20 piores distritos de São Paulo. Estado de São Paulo, http://fotos.estadao.com.br/galer 
ias/cidades,idh-os-20-melhores-e-os-20-piores-distritos-de-saopaulo,24925. Accessed January 29, 2020.

Estadão Conteúdo. 2019. MEC Contraria Discurso e Tira Verba da Educação Básica, Além de Faculdades. Exame, May 6, https:// exame.abril.com.br/brasil/mec-contraria-discurso-e-tira-verba -da-educacao-basica-alem-de-faculdades/. Accessed January 29, 2020.

Florida, R. 2002. The Rise of the Creative Class and How It's Transforming Work, Leisure, and Everyday Life. New York: Basic Books.

Florida, R. 2005. Cities and the Creative Class. London: Routledge. Florida, R. 2017. The New Urban Crisis: How Our Cities are Increasing Inequality, Deepening Segregation, and Failing the Middle Class—and What We Can Do About It. New York: Basic Books.

Friendly, A. 2017. Urban Policy, Social Movements, and the Right to the City in Brazil. Latin American Perspectives 44 (2): 132-148.

Gestão Urbana SP. n.d. Mapa dos Parklets em São Paulo, https://gesta ourbana.prefeitura.sp.gov.br/projetos-urbanos/parklets/mapa/. Accessed September 20, 2019.

Heben, Andrew. 2014. Tent City Urbanism: From Self-organized Camps to Tiny House Villages. Village Collaborative.

Hellman, J., et al. 2018. Jakarta: Claiming Spaces and Rights in the City. London and New York: Routledge.

Holston, J. 2008. Insurgent Citizenship: Disjunctions of Democracy and Modernity in Brazil. Princeton, NJ: Princeton University Press.

Hori, P. 2018. Práticas Urbanas Transformadoras: O Ativismo Urbano na Disputa por Espaços Públicos na Cidade de São Paulo. Master's thesis, University of São Paulo, São Paulo, http://www.teses .usp.br/teses/disponiveis/16/16135/tde-18102018-105115/pt-br. php. Accessed January 29, 2020.

Hou, J. 2010. Insurgent Public Space: Guerilla Urbanism and the Remaking of Contemporary Cities. London and New York: Routledge.

Jenks, Chris. 2004. Urban Culture: Critical Concepts in Literary and Cultural Studies, vol. 1. London and New York: Routledge.

Jiménez, A.C. 2014. The Right to Infrastructure: A Prototype for OpenSource Urbanism. Environment and Planning D: Society and Space 32: 342-362.

Jiménez, A.C., et al. n.d. Urbanisms in Beta, http://urbanbetas.cc/. Accessed January 29, 2020.

Kara José, B. 2009. Políticas Culturais e Negócios Urbanos. São Paulo: Fapesp, Annablume.

Kaltmeier, O. 2011. Selling EthniCity: Urban Cultural Politics in the Americas. Oxford: Ashgate.

KEA European Affairs. 2006. The Economy of Culture in Europe. Study prepared for the European Commisssion, DirectorateGeneral for Education and Culture, http://ec.europa.eu/assets/ eac/culture/library/studies/cultural-economy_en.pdf. Accessed January 29, 2020.

Keinert, T.M.M., and A.P. Karruz (eds.). 2002. Qualidade de Vida: Observatórios, Experiências e Metodologias. São Paulo: Annablume, Fapesp.

Kinder, K. 2016. DIY Detroit: Making Do in a City Without Services. Minneapolis: University of Minnesota Press.

Knudsen, B.T., et al. 2014. Enterprising Initiatives in the Experience Economy: Transforming Social Worlds. London: Routledge.

Kushins, J. 2013. Love or Hate It, User-Generated Urbanism May Be the Future of Cities. Gizmodo, September 23, https://gizmo do.com/love-it-or-hate-it-user-generated-urbanism-may-bethe-1344794381. Accessed January 29, 2020.

Kwak, A. 2018. A Progressist Entr'Acte in the Occupation of Public Space in the City of São Paulo. Revista Pós 25 (46): 12-31.

L., G. 2015. Facebook post, March 7.
LaFrombois, M. 2018. Reframing the Reclaiming of Urban Space: A Feminist Exploration into Do-It-Yourself Urbanism in Chicago. Lanham, MD: Lexington.

Lemos, J.A. 2010. Cultura e Política: O Caso do Programa "VAI" em São Paulo (2004-2008). PhD dissertation, Pontifical University of São Paulo, São Paulo, https://tede2.pucsp.br/handle/handl e/4200. Accessed January 29, 2020.

Lima, C.H.M. 2017. Cidade Consensual, Cidade Insurgente: Notas sobre o Ativismo Urbano no Centro de São Paulo. In Annals of the XVII Encontro Nacional da Associação Nacional de PósGraduação e Pesquisa em Planejamento Urbano e Regional, São Paulo, May 22-26, http://anais.anpur.org.br/index.php/anais enanpur/article/view/2231. Accessed January 29, 2020.

Low, S. 2000. On the Plaza: The Politics of Urban Space and Culture. Austin: University of Texas Press.

Low, S. 2017. Spatializing Culture: The Ethnography of Space and Place. New York: Routledge.

Lefebvre, H. 1991. The Production of Space. Cambridge, MA: Blackwell.

Lydon, M., et al. 2015. Tactical Urbanism: Short-Term Action for Long-Term Change. Washington: Island Press.

Mapa de Afetos. n.d. Mapa de Afetos online mapping platform, http:// sp.mapadeafetos.com/. Accessed September 20, 2019.

Mapping the Commons. n.d. Mapeando o Comum em São Paulo, https ://mappingthecommons.net/pt/sao-paulo/. Accessed January 29, 2020.

Marino, A. 2018. Ativismo e Apropriação do Espaço Urbano em São Paulo. Revista arq.urb 23: 170-184.

Mascarenhas, L.P. 2014. Reconversão Urbana do Largo da Batata: Revalorização e Novos Conteúdos da Centralidade de Pinheiros. Master's thesis, University of São Paulo, São Paulo, http:// www.teses.usp.br/teses/disponiveis/8/8136/tde-23012015-18395 8/pt-br.php. Accessed January 29, 2020.

Maziviero, M.C. and E. Almeida. 2017. Urbanismo Insurgente: ações recentes de coletivos urbanos ressignificando o espaço public na cidade de São Paulo. In Annals of the XVII Encontro Nacional da Associação Nacional de Pós-Graduação e Pesquisa em Planejamento Urbano e Regional, São Paulo, May 22-26, http:// anpur.org.br/xviienanpur/principal/publicacoes/XVII.ENANP UR_Anais/ST_Sessoes_Tematicas/ST\%206/ST\%206.1/ST\%20 6.1-04.pdf. Accessed January 29, 2020.

Mcdonogh, G., and C. Wong. 2005. Global Hong Kong. New York: Routledge.

Mesquita, A. 2008. Insurgências Poéticas: Arte Ativista e Ação Coletiva (1990-2000). Master's thesis, University of São Paulo, São Paulo.

Miazzo, F. 2014. We Own the City: Enabling Community Practice in Architecture and Urban Planning. Trancity.

Murphy, J., et al. 2014. Social Media in Public Opinion Research: Executive Summary of the AAPOR Task Force on Emerging Technologies in Public Opinion Research. Public Opinion Quarterly 78 (4): 788-794.

Nito, M.K.D.S., and S. Scifoni. 2018. Ativismo Urbano e Patrimônio Cultural. Revista arq.urb 23: 82-94.

Paddison, R., and S. Miles. 2007. Culture-Led Urban Regeneration. New York: Routledge.

Periferia em Movimento. n.d. Nosso Manifesto. Periferia em Movimento website, http://periferiaemmovimento.com.br/manifesto/. Accessed January 29, 2020.

Periferia Invisível. n.d. Sobre. Periferia Invisível website, https://www. periferiainvisivel.com.br/sobre/. Accessed January 29, 2020.

Prefeitura de São Paulo. 2002. Desigualdade em São Paulo: o IDH. Secretaria Municipal do Desenvolvimento, Trabalho e Solidariedade, https://www2.uol.com.br/aprendiz/n_noticias/imprescind ivel/id150802.doc. Accessed December 1, 2017. 
Prefeitura de São Paulo. 2014. Edital Redes e Ruas, Primeira Edição, http://www.prefeitura.sp.gov.br/cidade/upload/Redes $\% 20 \mathrm{e} \% 20$ Ruas_\%20primeira\%20edicao_1470695131.pdf. Accessed January 29, 2020.

Prefeitura de São Paulo. 2016. Programa de Fomento à Cultura da Periferia de São Paulo, http://www.prefeitura.sp.gov.br/cidade/secre tarias/cultura/cidadania_cultural/index.php?p=20403. Accessed January 29, 2020.

Prefeitura de São Paulo. n.d. Dados demográficos dos distritos pertencentes às prefeituras regionais. Portal da Prefeitura de São Paulo, http://www.prefeitura.sp.gov.br/cidade/secretarias/regio nais/subprefeituras/dados_demograficos/index.php? $\mathrm{p}=12758$. Accessed January 29, 2020.

Pretti, L. 2016. In-person Interview. São Paulo.

R., M. 2019. Corte ou Contingenciamento, Quem Está Certo na Guerra de Narrativas da Educação? El País Brasil, June 2, https://brasi 1.elpais.com/brasil/2019/05/31/politica/1559334689_18855 2.html. Accessed January 29, 2020.

Redação. 2019. Privatização do Parque do Ibirapuera Recebe Proposta de R \$ 70,5 Milhões. Destak Jornal, March 12, https://www.desta kjornal.com.br/cidades/sao-paulo/detalhe/privatizacao-do-parqu e-do-ibirapuera-recebe-proposta-de-r-705-milhoes. Accessed September 20, 2019.

Rosa, M., and U. Weiland. 2013. Handmade Urbanism: From Community Initiatives to Participatory Models. Berlin: Jovis.

Saldaña, P. 2019. Corte É Maior do que 30\% do Orçamento Livre em Mais da Metade das Federais. Folha de São Paulo, May 8, https ://www1.folha.uol.com.br/educacao/2019/05/corte-e-maior-doque-30-do-orcamento-livre-em-mais-da-metade-das-federais. shtml. Accessed January 29, 2020.

Sampaio, J. L. 2019. Para Oss, Corte de Verbas na Cultura Põe em Risco Principais Projetos Paulistas. Estadão, April 1, https:// cultura.estadao.com.br/blogs/joao-luiz-sampaio/para-oss-corte -de-verbas-na-cultura-poe-em-risco-principais-projetos-pauli stas/. Accessed January 29, 2020.

Secretaria da Cultura da Prefeitura de São Paulo. n.d. SP Cultura online mapping platform, http://spcultura.prefeitura.sp.gov.br/. Accessed January 29, 2020.

Seto, G. 2019. Gestão Covas Vai Alugar Áreas Embaixo de Viadutos. Folha de São Paulo, June 8, https://www1.folha.uol.com.br/cotid iano/2019/06/gestao-covas-vai-alugar-areas-embaixo-de-viadu tos-para-setor-privado.shtml. Accessed January 29, 2020.

Shareable. 2018. Sharing Cities: Activating the Urban Commons, https ://www.shareable.net/sharing-cities/. Accessed January 29, 2020.

Shepard, C. 2017. Citymakers: The Culture and Craft of Practical Urbanism. New York: Monacelli Press.

Silva, L. 2016. As Ruas São Para Dançar: Mapas, Labirintos e Caminhos no Baixocentro. Revista do Centro de Pesquisa e Formação 2 (May): 208-231.
Silva, P. 2016. Tactical Urbanism: Towards an Evolutionary Cities' Approach? Environment and Planning B: Urban Analytics and City Science 43 (6): 1040-1051.

Silva, B.J., and S.M. Pina. 2018. Produção Imaterial do Espaço e a Realização dos Desejos Urbanos. Revista arq.urb 23: 133-146.

Siwi, M. 2018. Grassroots Urbanism: Participatory Urban Planning in Post-WWII São Paulo. Public Lecture, Harvard University, March 8.

Stochero, T. 2019. Prefeitura de SP e Governo do Estado Assinam Chamamento para Projetos de Concessão das Marginais. Globo. com, February 27, https://g1.globo.com/sp/sao-paulo/notic ia/2019/02/27/prefeitura-de-sp-e-governo-do-estado-assinamchamamento-para-projetos-de-concessao-das-marginais.ghtml. Accessed January 29, 2020.

Soares, G. 2016. In-Person Interview. São Paulo.

Torres Freire, V. 2019. A Reforma dos Pobres e Miseráveis. Folha de São Paulo, February 22, https://www1.folha.uol.com.br/colunas/ viniciustorres/2019/02/a-reforma-dos-pobres-e-miseraveis.shtml . Accessed January 29, 2020.

UNESCO. 2013. Culture: Key to Sustainable Development. Hangzhou International Congress. Program and Proceedings, http://www. unesco.org/new/en/culture/themes/culture-and-development/ hangzhou-congress/. Accessed January 29, 2020.

UNESCO. 2016. Culture Urban Future. Global Report on Culture for Sustainable Urban Development, http://unesdoc.unesco.org/ images/0024/002462/246291E.pdf. Accessed January 29, 2020.

V., G. (2015). Facebook post, March 6. Accessed January 29, 2020.

Walljasper, J. 2007. The Great Neighborhood Book: A Do-It-Yourself Guide to Placemaking. Gabriola Island, BC: New Society Publishers; Project for Public Spaces.

Wassall, A., and L. Assad. 2018. Novos Atores na Humanização de Cidades. Ciência e Cultura 70 (1): 11-13. https://doi. org/10.21800/2317-66602018000100005.

Williams, R. 1975. The Country and the City. New York: Oxford University Press.

Williams, R. 1983. Culture and Society, 1780-1950. New York: Columbia University Press.

Wisnik, G. 2015. O Ativismo Urbano e o Valor de Uso do Espaço Público. Folha de São Paulo, November 15, https://www1.folha .uol.com.br/ilustrissima/2015/11/1705535-o-ativismo-urbano-eo-valor-de-uso-do-espaco-publico.shtml. Accessed January 29, 2020.

Wisnik, G. 2016. In-Person Interview. São Paulo.

Zukin, S. 1987. Gentrification: Culture and Capital in the Urban Core. Annual Review of Sociology 13: 129-147.

Publisher's Note Springer Nature remains neutral with regard to jurisdictional claims in published maps and institutional affiliations. 